Cite this: Mater. Chem. Front., 2018, 2, 537

Received 30th November 2017 Accepted 10th January 2018

DOI: $10.1039 / c 7 q m 00547 d$

rsc.li/frontiers-materials

\section{Enhancing the performance of the electron acceptor ITIC-Th via tailoring its end groups $\dagger$}

\author{
Zeyuan Li, $\ddagger^{\mathrm{a}}$ Shuixing Dai, $\ddagger^{\mathrm{a}}$ Jingming Xin, ${ }^{\mathrm{b}}$ Lin Zhang, ${ }^{\mathrm{b}}$ Yang $\mathrm{Wu},{ }^{\mathrm{b}}$ \\ Jeromy Rech, (D) C Fuwen Zhao, ${ }^{d}$ Tengfei Li, ${ }^{a}$ Kuan Liu, ${ }^{a}$ Qiao Liu, ${ }^{a}$ Wei Ma, \\ Wei You, (D) ${ }^{c}$ Chunru Wang (D) ${ }^{d}$ and Xiaowei Zhan (D) *a
}

\begin{abstract}
We choose the high-performance nonfullerene acceptor ITIC-Th as an example, and incorporate electron-donating methoxy and electron-withdrawing $\mathrm{F}$ groups onto the terminal group 1,1-dicyanomethylene3-indanone (IC) to construct a small library of four fused-ring electron acceptors. With this series, we systematically investigate the effects of the substituents on the end-groups on the electronic properties, charge transport, film morphology, and photovoltaic properties of the ITIC-Th series. The electron-withdrawing ability increases from methoxylated to unsubstituted, fluorinated, and difluorinated IC, leading to a downshift of energy levels and a redshift of absorption spectra. Optimized organic solar cells based on the ITIC-Th series show power conversion efficiencies ranging from $8.88 \%$ to $12.1 \%$.
\end{abstract}

\section{Introduction}

Organic solar cells (OSCs) are a promising technology for clean and renewable energy conversion. OSCs possess some advantages, such as low cost, semi-transparency, flexibility, and light weight. ${ }^{1-5}$ Fullerene derivatives (e.g., $\mathrm{PC}_{61} \mathrm{BM}$ and $\mathrm{PC}_{71} \mathrm{BM}$ ) are the classical electron acceptors used in OSCs for a long period of time. ${ }^{6,7}$ Blends of electron donating polymers or small molecules and fullerene derivatives exhibit power conversion efficiencies (PCEs) over $11 \%$. However, their shortcomings, such as weak absorption in the visible region and limited tunability in energy levels, restrict the further development of OSCs.

Nonfullerene acceptors present several advantages, such as enhanced absorption in the visible and even near-infrared (NIR) regions, adjustable energy levels and good device stability. ${ }^{8}$ For example, perylene diimide and naphthalene diimide small molecules and polymers are one class of high-performance nonfullerene acceptors, and have exhibited PCEs as high as 9-10\%. ${ }^{9-29}$

Since 2015, we have developed original fused-ring electron acceptors (FREAs) with an acceptor-donor-acceptor structure

\footnotetext{
${ }^{a}$ Department of Materials Science and Engineering, College of Engineering, Key Laboratory of Polymer Chemistry and Physics of Ministry of Education, Peking University, Beijing 100871, China.E-mail: xwzhan@pku.edu.cn

${ }^{b}$ State Key Laboratory for Mechanical Behavior of Materials,

Xi'an Jiaotong University, Xi'an 710049, China

${ }^{c}$ Department of Chemistry, University of North Carolina at Chapel Hill, Chapel Hill, North Carolina 27599-3290, USA

${ }^{d}$ Institute of Chemistry, Chinese Academy of Sciences, Beijing, 100190, China

$\dagger$ Electronic supplementary information (ESI) available: Synthesis and characterization of ITIC-Th2 and ITIC-Th3, device fabrication procedures, TGA and DSC curves, SCLC data, and AFM images. See DOI: 10.1039/c7qm00547d

‡ Zeyuan Li and Shuixing Dai contributed equally.
}

based on indacenodithiophene and indacenodithieno[3,2- $b]$ thiophene, end-capped with two electron-withdrawing terminal groups, 1,1-dicyanomethylene-3-indanone (IC). ${ }^{30-40}$ These FREAs exhibit broad and strong light absorption, and their LUMO and HOMO energy levels can be readily tuned. OSCs based on blends of FREAs and some high-performance donors have exhibited PCEs over $12 \% .^{41-47}$ For instance, we reported a highperformance nonfullerene acceptor, ITIC-Th, ${ }^{34}$ which showed a PCE of $9.6 \%$, when blended with a wide-bandgap polymer, PDBT-T1. ITIC-Th was also used by other groups and afforded PCEs of $10-11 \% .^{42,48}$

IC is the most commonly used electron-withdrawing terminal group in FREAs, and chemical modification on IC was employed to adjust molecular energy levels. For instance, the benzene on IC could be replaced with thiophene ${ }^{49,50}$ and naphthalene; ${ }^{51}$ the benzene on IC could be decorated by fluorine, ${ }^{52,53}$ chlorine, ${ }^{54}$ methyl $^{55}$ and methoxy groups. ${ }^{56}$ However, there have been rare systematic studies on the effects of substituents on IC. ${ }^{57,58}$

In this work, we choose the widely used ITIC-Th as an example, and incorporate electron-donating methoxy and electronwithdrawing $\mathrm{F}$ groups onto IC to construct a small library of four FREAs (ITIC-Th series, Fig. 1). With this series, we are able to systematically investigate the effects of the substituents on the end-groups on the electronic properties, charge transport, film morphology, and photovoltaic properties of the ITIC-Th series. The electron-withdrawing ability increases from methoxylated to unsubstituted, fluorinated, and difluorinated IC, leading to a downshift of energy levels and a redshift of absorption. Furthermore, optimized OSCs based on the ITIC-Th series show PCEs ranging from $8.88 \%$ to $12.1 \%$. 


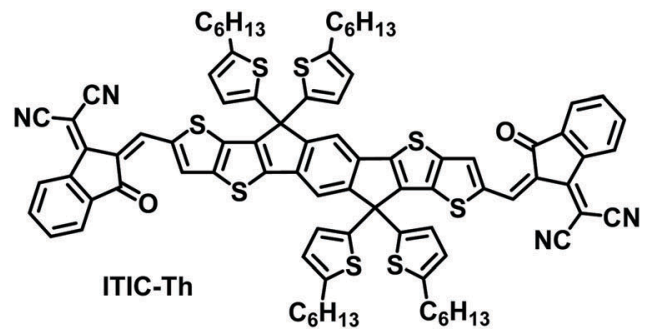

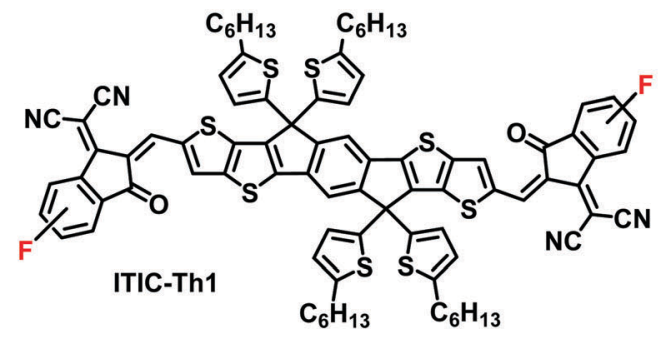

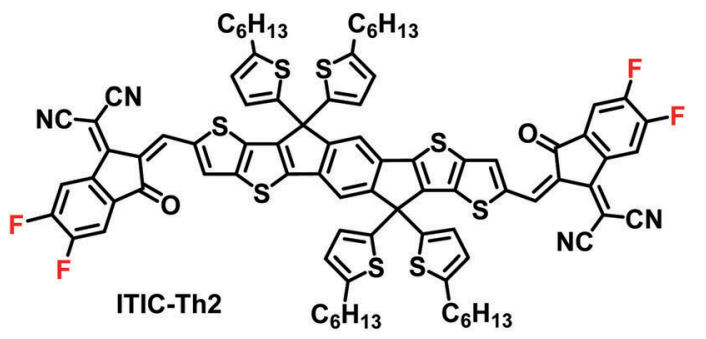

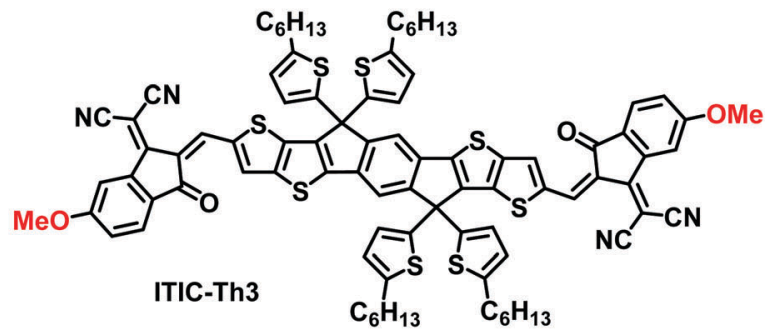

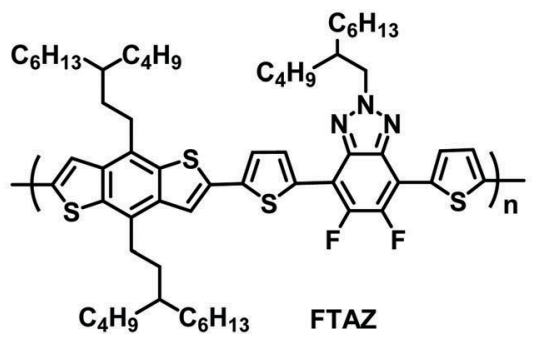

Fig. 1 Chemical structures of the ITIC-Th series acceptors and FTAZ donor.

\section{Results and discussion}

\section{Synthesis and characterization}

Two new FERAs, ITIC-Th2 and ITIC-Th3, were synthesized via the Knoevenagel condensation reaction (see Scheme S1 in the ESI $\dagger$ ). ITIC-Th2 and ITIC-Th3 were fully characterized by spectroscopic methods and elemental analysis. Both ITIC-Th2 and ITIC-Th3 show good solubility in common organic solvents, such as chloroform and dichloromethane. The thermal stability of ITIC-Th2 and ITIC-Th3 was investigated using thermogravimetric analysis (TGA) and differential scanning calorimetry (DSC) (Fig. S1 in the ESI $\dagger$ ). ITIC-Th2 and ITIC-Th3 show decomposition temperatures ( $T_{\mathrm{d}}, 5 \%$ weight loss) at $299^{\circ} \mathrm{C}$ and $333^{\circ} \mathrm{C}$, respectively.
The UV-vis absorption spectra of the ITIC-Th series in chloroform solution and as thin films were measured (Fig. 2); 4 molecules in solution show absorption peaks in the 664 to $680 \mathrm{~nm}$ range with molar extinction coefficients varying from $1.4 \times 10^{5}$ to $3.6 \times 10^{5} \mathrm{M}^{-1} \mathrm{~cm}^{-1}$ (Table 1 ). All molecules in thin films show broader and redshifted absorption relative to their solutions. The optical bandgaps of the ITIC-Th series are calculated to be 1.63 to $1.54 \mathrm{eV}$ from the absorption edge (Table 1). Relative to the parent ITIC-Th, fluorinated ITIC-Th1 and ITIC-Th2 have reduced bandgaps, while methoxylated ITIC-Th3 has a slightly larger bandgap.

The electrochemical properties of the four FERAs were investigated by cyclic voltammetry (Fig. 3a). Assuming the
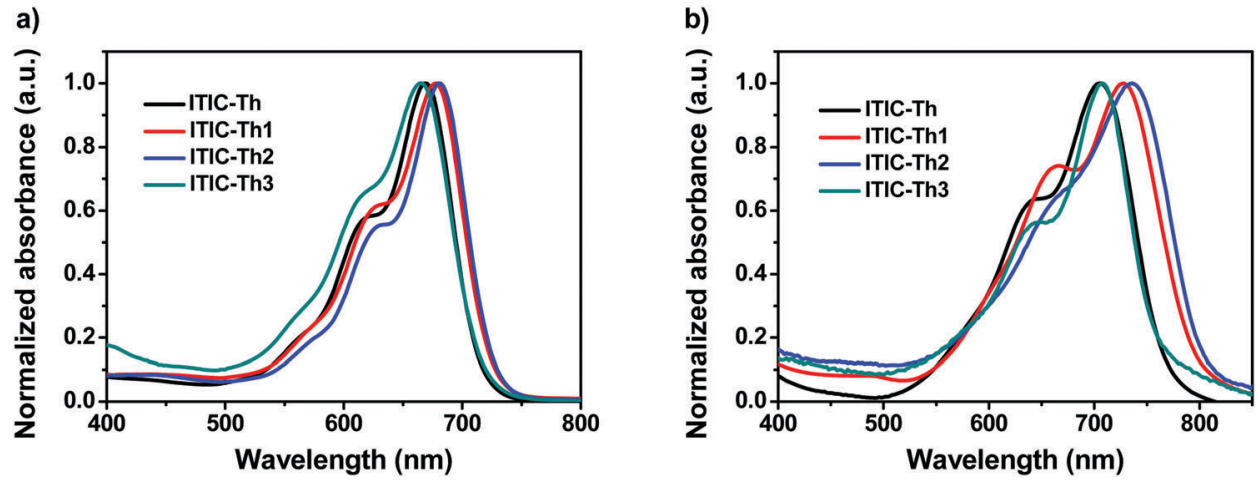

Fig. 2 Absorption spectra of the ITIC-Th series in chloroform solution (a) and as thin films (b). 
Table 1 Properties of the ITIC-Th series

\begin{tabular}{lllllllll}
\hline Compound & $T_{\mathrm{d}}{ }^{a}\left({ }^{\circ} \mathrm{C}\right)$ & $\lambda_{\mathrm{s}, \max }{ }^{b}(\mathrm{~nm})$ & $\lambda_{\mathrm{f}, \max }{ }^{c}(\mathrm{~nm})$ & $\varepsilon_{\max }{ }^{d}\left(\mathrm{M}^{-1} \mathrm{~cm}^{-1}\right)$ & $E_{\mathrm{g}}{ }^{e}(\mathrm{eV})$ & $\mathrm{HOMO}^{f}\left(\mathrm{eV}^{2}\right.$ & $\mathrm{LUMO}^{g}\left(\mathrm{eV}^{2}\right)$ & $\mu_{\mathrm{e}}{ }^{h}\left(\mathrm{~cm}^{2} \mathrm{~V}^{-1} \mathrm{~s}^{-1}\right)$ \\
\hline ITIC-Th & $310^{i}$ & 668 & 706 & $1.5 \times 10^{5}$ & 1.60 & -5.66 & -3.93 & $2 \times 10^{-4}$ \\
ITIC-Th1 & $271^{j}$ & 677 & 728 & $1.8 \times 10^{5}$ & 1.55 & -5.74 & -4.01 & $5 \times 10^{-4}$ \\
ITIC-Th2 & 299 & 680 & 735 & $3.6 \times 10^{5}$ & 1.54 & -5.75 & -4.07 & $2 \times 10^{-4}$ \\
ITIC-Th3 & 333 & 664 & 698 & $1.4 \times 10^{5}$ & 1.63 & -5.67 & -3.73 & $5 \times 10^{-4}$
\end{tabular}

${ }^{a}$ Decomposition temperature measured from TGA. ${ }^{b}$ Absorption maximum in solution. ${ }^{c}$ Absorption maximum in films. ${ }^{d}$ Molar extinction coefficient at $\lambda_{\max }$ in solution. ${ }^{e}$ Optical bandgap calculated from the absorption edge of the thin film. ${ }^{f}$ Estimated from the onset oxidation potential. ${ }^{g}$ Estimated from the onset reduction potential. ${ }^{h}$ Electron mobility measured by the SCLC method. ${ }^{i}$ Taken from ref. $34 .{ }^{j}$ Taken from ref. 53.

absolute energy level of $\mathrm{FeCp}_{2}{ }^{+/ 0}$ to be $4.8 \mathrm{eV}$ below vacuum, the HOMO and LUMO energy levels were calculated from the onset oxidation and reduction potentials, respectively. The HOMO energy levels of the 4 molecules range from $-5.66 \mathrm{eV}$ to $-5.75 \mathrm{eV}$, while the LUMO energy levels range from $-3.73 \mathrm{eV}$ to $-4.07 \mathrm{eV}$ (Table 1). Relative to the parent ITIC-Th, methoxylated ITIC-Th3 exhibits a similar HOMO but a significantly upshifted LUMO, due to the electron-donating effect of the methoxy group. Relative to the parent ITIC-Th, fluorinated ITIC-Th1 and ITIC-Th2 exhibit a downshifted HOMO and a downshifted LUMO, due to the electron-withdrawing effect of the fluorine atom (Fig. 3b).

The electron mobilities of the 4 compounds were measured using the space charge-limited current (SCLC) method (Fig. S2, ESI $\dagger)$. The electron mobilities of ITIC-Th, ITIC-Th1, ITIC-Th2 and ITIC-Th3 are $2 \times 10^{-4}, 5 \times 10^{-4}, 2 \times 10^{-4}$, and $5 \times$ $10^{-4} \mathrm{~cm}^{2} \mathrm{~V}^{-1} \mathrm{~s}^{-1}$, respectively (Table 1 ). Monofluorinated ITICTh1 and methoxylated ITIC-Th3 exhibit higher mobilities than the parent ITIC-Th and difluorinated ITIC-Th2.

\section{Photovoltaic properties}

Our previously reported wide-bandgap polymer donor FTAZ (Fig. 1) exhibits strong absorption at 400-620 nm with a molar extinction coefficient of $9.8 \times 10^{4} \mathrm{M}^{-1} \mathrm{~cm}^{-1},{ }^{59}$ which complements the absorption spectra of the ITIC-Th series. The energy levels of FTAZ match with those of the ITIC-Th series (Fig. 3b). Moreover, FTAZ exhibits a hole mobility as high as $1.2 \times 10^{-3} \mathrm{~cm}^{2} \mathrm{~V}^{-1} \mathrm{~s}^{-1} \cdot 60$ Thus, we used FTAZ as the donor and the ITIC-Th series as the acceptors to fabricate bulk heterojunction (BHJ) OSCs with an inverted device structure of indium tin oxide (ITO)/ZnO/FTAZ:
acceptor/MoOx/Ag. The optimized FTAZ/acceptor weight ratio is $1: 1.5$, and the optimized content for the processing additive, 1,8-diiodooctane (DIO), is $0.25 \%(\mathrm{v} / \mathrm{v})$ when using chloroform as processing solvent. The $J-V$ curves of the best devices based on blends of the FTAZ:ITIC-Th series are shown in Fig. 4a.

Relative to the ITIC-Th-based devices (0.915 V), the ITIC-Th1 and ITIC-Th2-based OSCs exhibit lower open-circuit voltages $\left(V_{\mathrm{OC}}\right)(0.849 \mathrm{~V}$ and $0.751 \mathrm{~V}$, respectively), due to the lower LUMOs of ITIC-Th1 and ITIC-Th2 (Table 2); while the ITICTh3-based OSCs exhibit higher $V_{\mathrm{OC}}(0.962 \mathrm{~V})$, due to the elevated LUMO of ITIC-Th3. Compared to the ITIC-Th and ITIC-Th3-based devices, the ITIC-Th1 and ITIC-Th2-based devices show higher short-circuit current density $\left(J_{\mathrm{SC}}\right)$ and higher fill factors (FF), which are partially caused by redshifted and stronger absorption and the stronger intermolecular interaction caused by the fluorine atoms. The best PCE of the OSCs based on the parent ITIC-Th is $8.88 \%$, while the best PCEs of the OSCs based on monofluorinated ITIC-Th1 and difluorinated ITIC-Th2 are $12.1 \%$ and $9.06 \%$, respectively, and the best PCE of the OSCs based on methoxylated ITIC-Th3 is $10.7 \%$. Fluorination and methoxylation of the IC unit indeed enhance device performance; in particular, the monofluorinated ITIC-Th1 performs best.

The external quantum efficiency (EQE) spectra of the OSCs based on blends of the FTAZ:ITIC-Th series are shown in Fig. 4b. The OSCs based on these four ITIC-Th series acceptors show a broad photoresponse extending from 300 to $850 \mathrm{~nm}$. In the NIR region, the EQE spectra are broadened and enhanced from ITIC-Th and ITIC-Th3 to ITIC-Th1 and ITIC-Th2, resembling their absorption profiles in the NIR region (Fig. 2b).
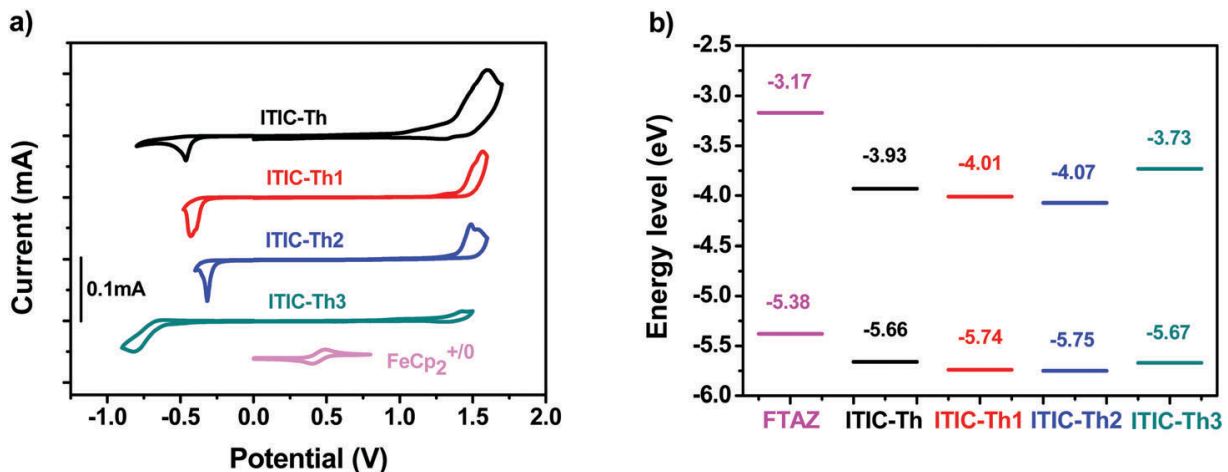

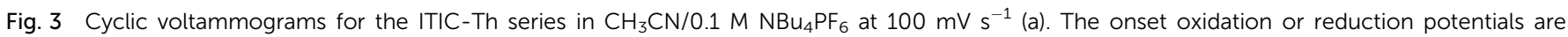

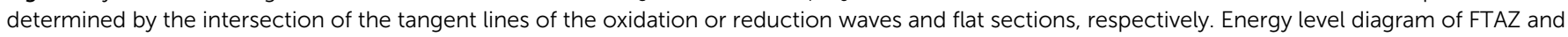
the ITIC-Th series (b). 
a)

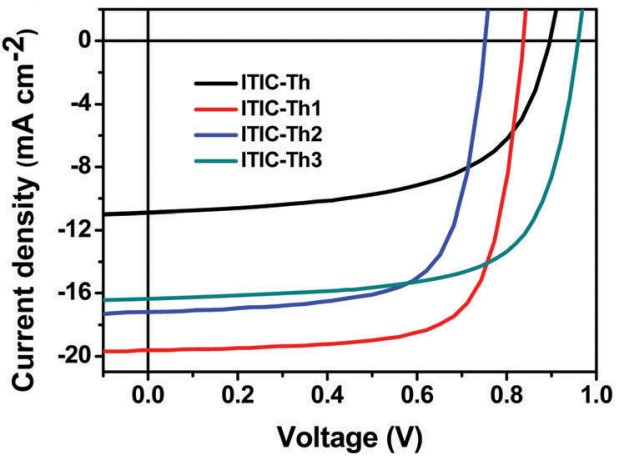

b)

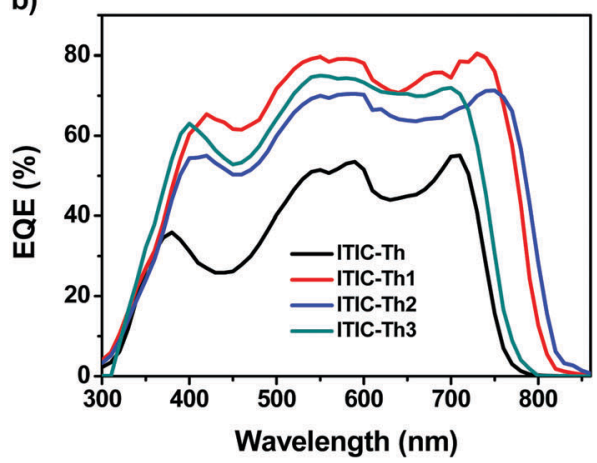

Fig. 4 Current density versus voltage characteristics (a) and EQE curves of devices based on FTAZ:ITIC-Th series blends (b).

Table 2 Photovoltaic performance of OSCs based on the ITIC-Th series ${ }^{a}$

\begin{tabular}{lllll}
\hline Device & $V_{\mathrm{OC}}(\mathrm{V})$ & $J_{\mathrm{SC}}\left(\mathrm{mA} \mathrm{cm}^{-2}\right)$ & FF $(\%)$ & PCE $(\%)$ \\
\hline FTAZ:ITIC-Th & $0.915(0.914 \pm 0.003)$ & $15.84(15.67 \pm 0.23)$ & $61.26(61.14 \pm 0.86)$ & $8.88(8.67 \pm 0.15)$ \\
FTAZ:ITIC-Th1 & $0.849(0.847 \pm 0.002)$ & $19.33(19.22 \pm 0.18)$ & $73.73(72.56 \pm 0.29)$ & $12.1(11.9 \pm 0.1)$ \\
FTAZ:ITIC-Th2 & $0.751(0.748 \pm 0.004)$ & $17.19(16.97 \pm 0.25)$ & $70.07(69.34 \pm 0.77)$ & $9.06(8.93 \pm 0.15)$ \\
FTAZ:ITIC-Th3 & $0.962(0.960 \pm 0.003)$ & $16.34(16.26 \pm 0.13)$ & $68.33(68.12 \pm 0.25)$ & $10.7(10.6 \pm 0.15)$
\end{tabular}

${ }^{a}$ FTAZ/acceptor $=1: 1.5(\mathrm{w} / \mathrm{w}), 0.25 \%$ DIO $(\mathrm{v} / \mathrm{v})$; average data in brackets are obtained from 20 devices.

We measured $J_{\mathrm{SC}}$ as a function of incident light intensity $(P)$ and the data were fitted to the power law: $J_{\mathrm{SC}} \propto P^{\alpha}$, to study charge recombination in the devices (Fig. 5a). ${ }^{61}$ The exponent $\alpha$ for ITIC-Th series-based cells is 0.98 to 0.99 , indicating very weak bimolecular recombination under short circuit conditions in the active layers of all devices. We also measured the photocurrent density $\left(J_{\mathrm{ph}}\right)$ versus the effective voltage $\left(V_{\text {eff }}\right)$ to investigate their charge generation, dissociation and extraction properties (Fig. 5b). It is assumed that all the photogenerated excitons are dissociated into free charge carriers and collected by electrodes at a high $V_{\text {eff }}$ (that is, $V_{\text {eff }}=2 \mathrm{~V}$ ), so the saturation photocurrent density $\left(J_{\text {sat }}\right)$ is only limited by the total amount of absorbed incident photons. ${ }^{62}$ The $J_{\text {sat }}$ values of the ITIC-Th, ITIC-Th1, ITIC-Th2 and ITIC-Th3-based solar cells are $16.37,20.51,17.93$, and $16.52 \mathrm{~mA} \mathrm{~cm}^{-2}$, respectively. Fluorinated ITIC-Th1 and ITIC-Th2 show relatively higher $J_{\text {sat }}$, partially due to better light harvesting and exciton generation.
The $J_{\text {SC }} / J_{\text {sat }}$ values for the ITIC-Th series are $>95 \%$, indicating excellent charge extraction in all devices.

The hole mobilities and electron mobilities of the blended films were measured using the SCLC method (Fig. S3 and Table S1, ESI $\dagger$ ). The blended films based on FTAZ:modified ITIC-Th exhibit higher electron mobility and therefore more balanced charge transport relative to the one based on FTAZ:parent ITIC-Th, which is responsible for the higher FFs of their devices.

\section{Film morphology}

Atomic force microscopy (AFM) images of FTAZ:ITIC-Th series blends are shown in Fig. S4 (ESI $\dagger$ ). The root-mean-square roughnesses of ITIC-Th, ITIC-Th1, ITIC-Th2 and ITIC-Th3-based blended films are $0.80,0.76,0.99$ and $0.82 \mathrm{~nm}$, respectively. All films have a smooth and uniform surface.

Grazing incidence wide angle X-ray scattering (GIWAXS) measurements were employed to characterize the molecular
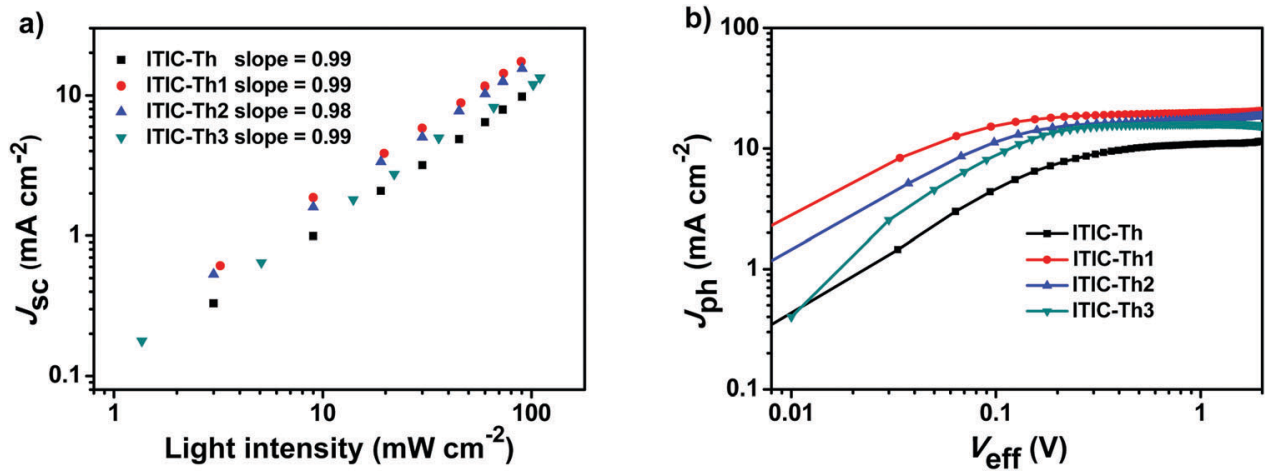

Fig. 5 Dependence of $J_{S C}$ on light intensity (a); and photocurrent density versus effective voltage curves (b). 

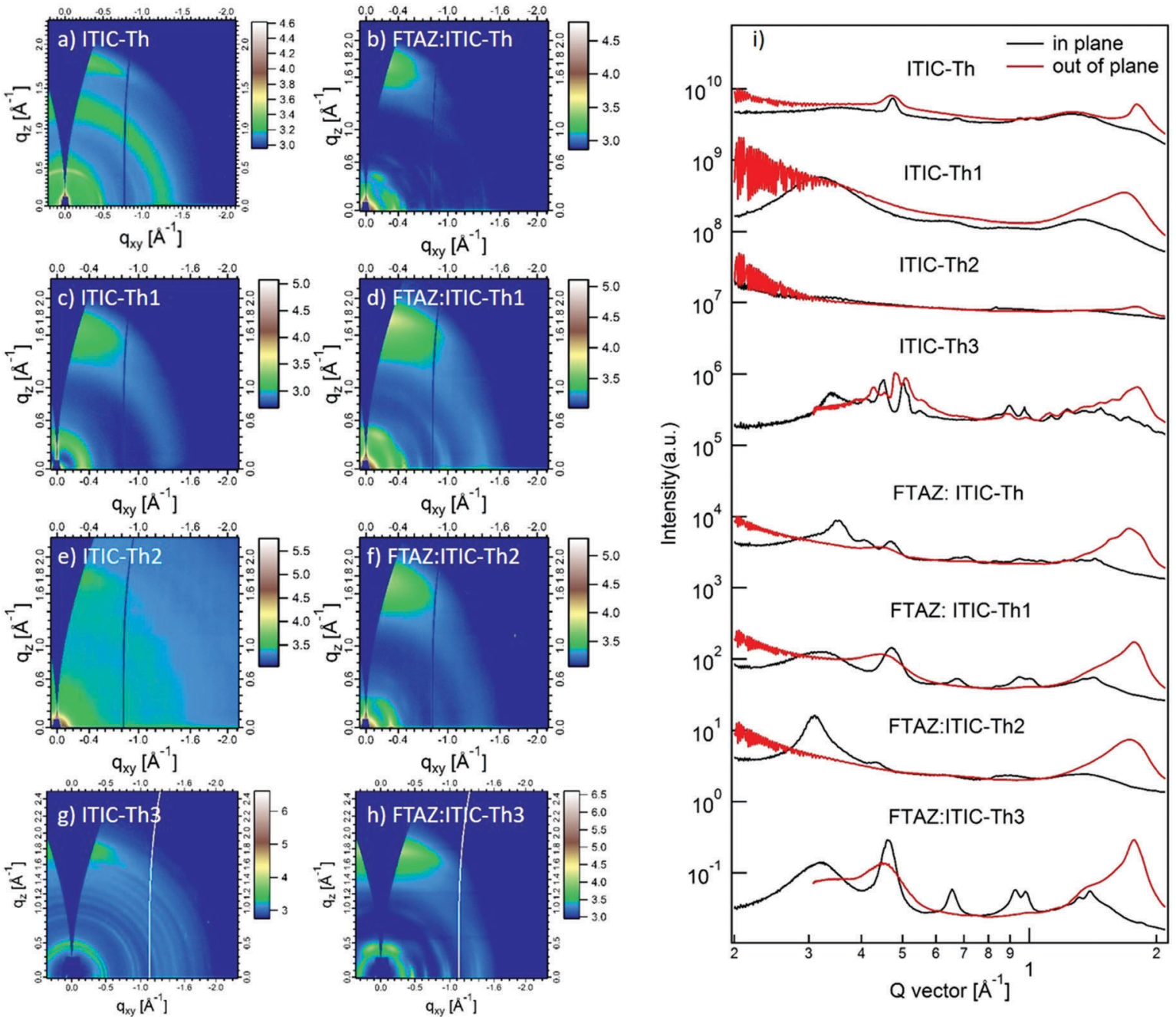
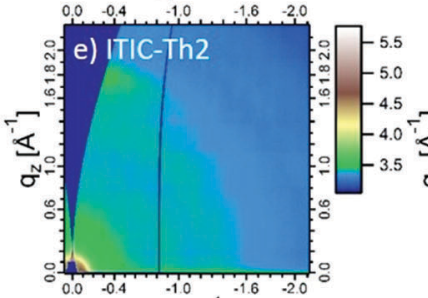

$\mathrm{q}_{\mathrm{xy}}\left[\mathrm{A}^{-1}\right]$

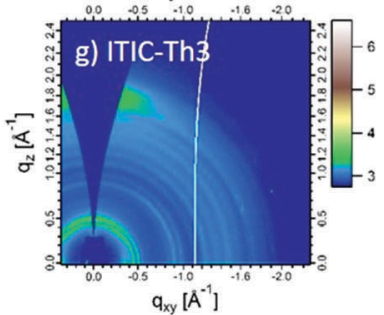

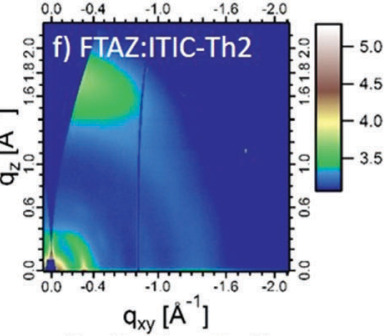

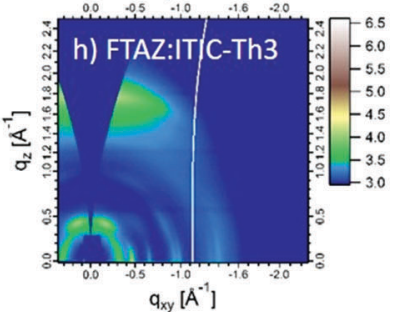

Fig. 6 2D GIWAXS patterns and scattering profiles (in-plane and out-of-plane) for ITIC-Th series neat and blended films.

packing and crystallinity of the neat and blended films (Fig. 6). ${ }^{63}$ Overall, the neat films of fluorinated ITIC-Th1 and ITIC-Th2 show decreased crystallinity, while methoxyl-modified ITIC-Th3 exhibits strong ordered packing with three sharp lamellar stacking peaks. After being blended with FTAZ, almost all the peaks of FTAZ:ITIC-Th1 are stronger/sharper, compared with FTAZ:ITIC-Th. The (010) peaks for FTAZ:ITIC-Th, FTAZ: ITIC-Th1 and FTAZ:ITIC-Th2 locate at $\sim 1.8 \AA$ with coherence lengths of 3.7, 4.0 and $2.0 \mathrm{~nm}$, respectively. Similar to the neat film, the FTAZ:ITIC-Th3 blend shows a sharp (010) peak at $1.78 \AA^{-1}$ with a coherence length of $4.3 \mathrm{~nm}$. The improved molecular packing is known to benefit the charge transport. Thus, FTAZ:modified ITIC-Th blends show higher mobility, which leads to higher FFs, relative to the FTAZ:parent ITIC-Th blend.

Resonant soft X-ray scattering (R-SoXS) was utilized to characterize the phase separation in the active layer of four blends. ${ }^{64}$ The photon energy of $286.8 \mathrm{eV}$ is selected to enhance the material contrasts. The phase separation length scale $\xi$, so-called domain spacing, can be obtained from the equation $\xi=2 \pi / q$ and the domain size is half of $\xi$. The scattering profiles are fitted by $\log$ normal distributions (Fig. 7). The mode

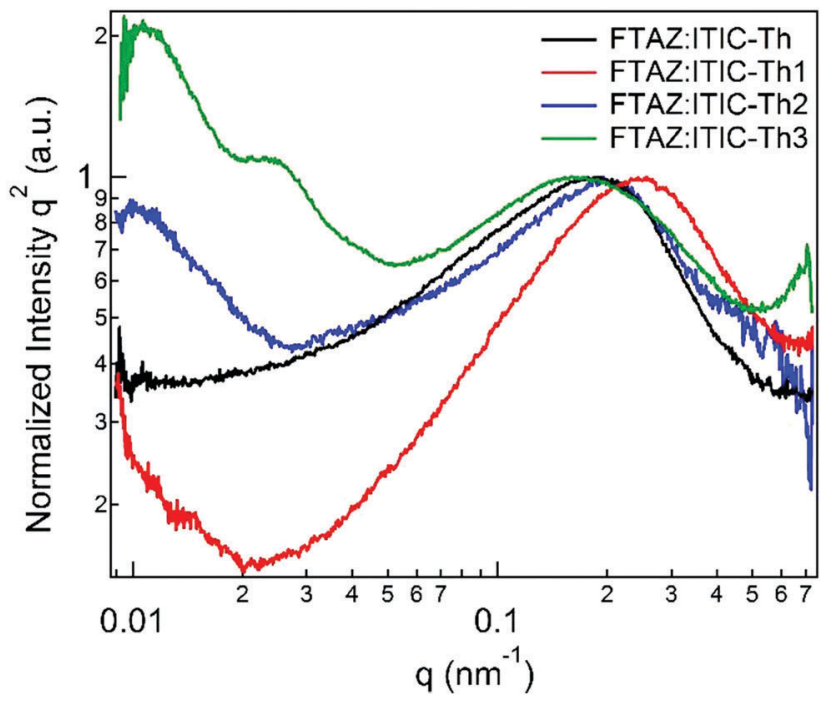

Fig. 7 Normalized R-SoXS profiles on a log scale for FTAZ:ITIC-Th series blended films. 
domain sizes of ITIC-Th, ITIC-Th1, ITIC-Th2 and ITIC-Th3 based blend films are calculated to be 15, 13, 15 and $20 \mathrm{~nm}$, respectively. As the exciton diffusion length is limited to 10-20 nm, smaller domain size is favorable for the charge separation. Therefore, FTAZ:ITIC-Th1 achieves the highest $J_{\mathrm{SC}}$.

\section{Conclusions}

We incorporate electron-donating methoxy and electronwithdrawing $\mathrm{F}$ groups onto the terminal group IC in the widely used nonfullerene acceptor ITIC-Th, and investigate the effects of the substituents on the end-groups on the electronic properties, charge transport, film morphology, and photovoltaic properties of the ITIC-Th series. Compared with the parent ITIC-Th, fluorinated ITIC-Th1 and ITIC-Th2 show lower HOMO and lower LUMO energy levels, red-shifted absorption, and smaller bandgaps, while ITIC-Th3 exhibits a similar HOMO but a higher LUMO level, slightly blue-shifted absorption and a slightly larger bandgap. Monofluorinated ITIC-Th1 and methoxylated ITIC-Th3 exhibit higher mobility than the parent ITIC-Th and difluorinated ITIC-Th2. FTAZ:modified ITIC-Th blended films exhibit stronger molecular packing and longer coherence length, leading to higher electron mobilities and balanced charge transport, which are responsible for the higher FFs of their devices relative to FTAZ:parent ITIC-Th. Moreover, FTAZ:ITIC-Th1 films present relatively smaller domain sizes to afford more D/A interfaces for exciton dissociation. OSCs based on FTAZ:ITIC-Th1 exhibit PCEs as high as $12.1 \%$, higher than those based on FTAZ: ITIC-Th (8.88\%), FTAZ:ITIC-Th2 (9.06\%) and FTAZ:ITIC-Th3 $(10.7 \%)$. Our results demonstrate that subtle tailoring on endgroups can significantly boost the performance of the nonfullerene acceptor.

\section{Conflicts of interest}

There are no conflicts to declare.

\section{Acknowledgements}

X. Z. wish to thank NSFC (No. 21734001 and 51761165023). W. Y. thanks NSF (DMR-1507249 and CBET-1639429). W. M. thanks the Ministry of Science and Technology of China (2016YFA0200700) and NSFC (21504066 and 21534003). X-ray data was acquired at beamlines 7.3.3 and 11.0.1.2 at the Advanced Light Source, which was supported by the Director, Office of Science, Office of Basic Energy Sciences, of the U. S. Department of Energy under Contract No. DE-AC02-05CH11231. The authors thank Chenhui Zhu at beamline 7.3.3, and Cheng Wang at beamline 11.0.1.2 for assistance with data acquisition.

\section{References}

1 G. Li, R. Zhu and Y. Yang, Nat. Photonics, 2012, 6, 153.

2 Y. Lin, Y. Li and X. Zhan, Chem. Soc. Rev., 2012, 41, 4245.
3 F. C. Krebs, N. Espinosa, M. Hösel, R. R. Søndergaard and M. Jørgensen, Adv. Mater., 2014, 26, 29.

4 L. Lu, T. Zheng, Q. Wu, A. M. Schneider, D. Zhao and L. Yu, Chem. Rev., 2015, 115, 12666.

5 J. Wang, K. Liu, L. Ma and X. Zhan, Chem. Rev., 2016, 116, 14675.

6 J. E. Anthony, A. Facchetti, M. Heeney, S. R. Marder and X. Zhan, Adv. Mater., 2010, 22, 3876.

7 Y. He and Y. Li, Phys. Chem. Chem. Phys., 2011, 13, 1970.

8 Y. Lin and X. Zhan, Mater. Horiz., 2014, 1, 470.

9 X. Zhan, Z. a. Tan, B. Domercq, Z. An, X. Zhang, S. Barlow, Y. Li, D. Zhu, B. Kippelen and S. R. Marder, J. Am. Chem. Soc., 2007, 129, 7246.

10 X. Zhan, A. Facchetti, S. Barlow, T. J. Marks, M. A. Ratner, M. R. Wasielewski and S. R. Marder, Adv. Mater., 2011, 23, 268.

11 T. Earmme, Y.-J. Hwang, N. M. Murari, S. Subramaniyan and S. A. Jenekhe, J. Am. Chem. Soc., 2013, 135, 14960.

12 H. Li, F. S. Kim, G. Ren, E. C. Hollenbeck, S. Subramaniyan and S. A. Jenekhe, Angew. Chem., Int. Ed., 2013, 52, 5513.

13 X. Zhang, Z. Lu, L. Ye, C. Zhan, J. Hou, S. Zhang, B. Jiang, Y. Zhao, J. Huang, S. Zhang, Y. Liu, Q. Shi, Y. Liu and J. Yao, Adv. Mater., 2013, 25, 5791.

14 E. Zhou, J. Cong, K. Hashimoto and K. Tajima, Adv. Mater., 2013, 25, 6991.

15 P. Cheng, L. Ye, X. Zhao, J. Hou, Y. Li and X. Zhan, Energy Environ. Sci., 2014, 7, 1351.

16 P. E. Hartnett, A. Timalsina, H. S. S. R. Matte, N. Zhou, X. Guo, W. Zhao, A. Facchetti, R. P. H. Chang, M. C. Hersam, M. R. Wasielewski and T. J. Marks, J. Am. Chem. Soc., 2014, 136, 16345.

17 Y. Lin, Y. Wang, J. Wang, J. Hou, Y. Li, D. Zhu and X. Zhan, Adv. Mater., 2014, 26, 5137.

18 R. Shivanna, S. Shoaee, S. Dimitrov, S. K. Kandappa, S. Rajaram, J. R. Durrant and K. S. Narayan, Energy Environ. Sci., 2014, 7, 435.

19 H. Li, Y.-J. Hwang, B. A. E. Courtright, F. N. Eberle, S. Subramaniyan and S. A. Jenekhe, Adv. Mater., 2015, 27, 3266.

20 Y. Liu, C. Mu, K. Jiang, J. Zhao, Y. Li, L. Zhang, Z. Li, J. Y. L. Lai, H. Hu, T. Ma, R. Hu, D. Yu, X. Huang, B. Z. Tang and H. Yan, Adv. Mater., 2015, 27, 1015.

21 D. Sun, D. Meng, Y. Cai, B. Fan, Y. Li, W. Jiang, L. Huo, Y. Sun and Z. Wang, J. Am. Chem. Soc., 2015, 137, 11156.

22 Y. Zhong, M. T. Trinh, R. Chen, G. E. Purdum, P. P. Khlyabich, M. Sezen, S. Oh, H. Zhu, B. Fowler, B. Zhang, W. Wang, C.-Y. Nam, M. Y. Sfeir, C. T. Black, M. L. Steigerwald, Y.-L. Loo, F. Ng, X. Y. Zhu and C. Nuckolls, Nat. Commun., 2015, 6, 8242.

23 L. Gao, Z.-G. Zhang, L. Xue, J. Min, J. Zhang, Z. Wei and Y. Li, Adv. Mater., 2016, 28, 1884.

24 Y. Guo, Y. Li, O. Awartani, J. Zhao, H. Han, H. Ade, D. Zhao and H. Yan, Adv. Mater., 2016, 28, 8483.

25 J. Liu, S. Chen, D. Qian, B. Gautam, G. Yang, J. Zhao, J. Bergqvist, F. Zhang, W. Ma, H. Ade, O. Inganäs, K. Gundogdu, F. Gao and H. Yan, Nat. Energy, 2016, 1, 16089.

26 D. Meng, H. Fu, C. Xiao, X. Meng, T. Winands, W. Ma, W. Wei, B. Fan, L. Huo, N. L. Doltsinis, Y. Li, Y. Sun and Z. Wang, J. Am. Chem. Soc., 2016, 138, 10184.

27 Q. Wu, D. Zhao, A. M. Schneider, W. Chen and L. Yu, J. Am. Chem. Soc., 2016, 138, 7248. 
28 D. Zhao, Q. Wu, Z. Cai, T. Zheng, W. Chen, J. Lu and L. Yu, Chem. Mater., 2016, 28, 1139.

29 H. Zhong, C.-H. Wu, C.-Z. Li, J. Carpenter, C.-C. Chueh, J.-Y. Chen, H. Ade and A. K. Y. Jen, Adv. Mater., 2016, 28, 951.

30 Y. Lin, J. Wang, Z. G. Zhang, H. Bai, Y. Li, D. Zhu and X. Zhan, Adv. Mater., 2015, 27, 1170.

31 Y. Lin and X. Zhan, Adv. Energy Mater., 2015, 5, 1501063.

32 Y. Lin, Q. He, F. Zhao, L. Huo, J. Mai, X. Lu, C. J. Su, T. Li, J. Wang, J. Zhu, Y. Sun, C. Wang and X. Zhan, J. Am. Chem. Soc., 2016, 138, 2973.

33 Y. Lin, T. Li, F. Zhao, L. Han, Z. Wang, Y. Wu, Q. He, J. Wang, L. Huo, Y. Sun, C. Wang, W. Ma and X. Zhan, Adv. Energy Mater., 2016, 6, 1600854.

34 Y. Lin, F. Zhao, Q. He, L. Huo, Y. Wu, T. C. Parker, W. Ma, Y. Sun, C. Wang, D. Zhu, A. J. Heeger, S. R. Marder and X. Zhan, J. Am. Chem. Soc., 2016, 138, 4955.

35 P. Cheng, M. Zhang, T.-K. Lau, Y. Wu, B. Jia, J. Wang, C. Yan, M. Qin, X. Lu and X. Zhan, Adv. Mater., 2017, 29, 1605216.

36 J. Zhu, Z. Ke, Q. Zhang, J. Wang, S. Dai, Y. Wu, Y. Xu, Y. Lin, W. Ma, W. You and X. Zhan, Adv. Mater., 2018, 30, 1704713.

37 Y. Lin, F. Zhao, Y. Wu, K. Chen, Y. Xia, G. Li, S. K. K. Prasad, J. Zhu, L. Huo, H. Bin, Z.-G. Zhang, X. Guo, M. Zhang, Y. Sun, F. Gao, Z. Wei, W. Ma, C. Wang, J. Hodgkiss, Z. Bo, O. Inganäs, Y. Li and X. Zhan, Adv. Mater., 2017, 29, 1604155.

38 T. Li, Z. Ke, L. Yang, J. Wang, C. Yan, W. Ma and X. Zhan, Adv. Mater., 2018, 30, 1705969.

39 J. Wang, W. Wang, X. Wang, Y. Wu, Q. Zhang, C. Yan, W. Ma, W. You and X. Zhan, Adv. Mater., 2017, 29, 1702125.

40 W. Wang, C. Yan, T.-K. Lau, J. Wang, K. Liu, Y. Fan, X. Lu and X. Zhan, Adv. Mater., 2017, 29, 1701308.

41 H. Bin, L. Gao, Z.-G. Zhang, Y. Yang, Y. Zhang, C. Zhang, S. Chen, L. Xue, C. Yang, M. Xiao and Y. Li, Nat. Commun., 2016, 7, 13651.

42 Z. Li, K. Jiang, G. Yang, J. Y. L. Lai, T. Ma, J. Zhao, W. Ma and H. Yan, Nat. Commun., 2016, 7, 13094.

43 Y. Yang, Z. G. Zhang, H. Bin, S. Chen, L. Gao, L. Xue, C. Yang and Y. Li, J. Am. Chem. Soc., 2016, 138, 15011.

44 W. Zhao, D. Qian, S. Zhang, S. Li, O. Inganäs, F. Gao and J. Hou, Adv. Mater., 2016, 28, 4734.

45 D. Baran, R. S. Ashraf, D. A. Hanifi, M. Abdelsamie, N. Gasparini, J. A. Rohr, S. Holliday, A. Wadsworth, S. Lockett, M. Neophytou, C. J. M. Emmott, J. Nelson, C. J. Brabec, A. Amassian, A. Salleo, T. Kirchartz, J. R. Durrant and I. McCulloch, Nat. Mater., 2017, 16, 363.
46 B. Kan, H. Feng, X. Wan, F. Liu, X. Ke, Y. Wang, Y. Wang, H. Zhang, C. Li, J. Hou and Y. Chen, J. Am. Chem. Soc., 2017, 139, 4929.

47 Y. Liu, Z. Zhang, S. Feng, M. Li, L. Wu, R. Hou, X. Xu, X. Chen and Z. Bo, J. Am. Chem. Soc., 2017, 139, 3356.

48 T. Liu, Y. Guo, Y. Yi, L. Huo, X. Xue, X. Sun, H. Fu, W. Xiong, D. Meng, Z. Wang, F. Liu, T. P. Russell and Y. Sun, Adv. Mater., 2016, 28, 10008.

49 D. Xie, T. Liu, W. Gao, C. Zhong, L. Huo, Z. Luo, K. Wu, W. Xiong, F. Liu, Y. Sun and C. Yang, Solar RRL, 2017, 1, p. 1700044.

50 H. Yao, L. Ye, J. Hou, B. Jang, G. Han, Y. Cui, G. M. Su, C. Wang, B. Gao, R. Yu, H. Zhang, Y. Yi, H. Y. Woo, H. Ade and J. Hou, Adv. Mater., 2017, 29, 1700254.

51 H. Feng, N. Qiu, X. Wang, Y. Wang, B. Kan, X. Wan, M. Zhang, A. Xia, C. Li, F. Liu, H. Zhang and Y. Chen, Chem. Mater., 2017, 29, 7908.

52 S. Dai, F. Zhao, Q. Zhang, T. K. Lau, T. Li, K. Liu, Q. Ling, C. Wang, X. Lu, W. You and X. Zhan, J. Am. Chem. Soc., 2017, 139, 1336.

53 F. Zhao, S. Dai, Y. Wu, Q. Zhang, J. Wang, L. Jiang, Q. Ling, Z. Wei, W. Ma, W. You, C. Wang and X. Zhan, Adv. Mater., 2017, 29, 1700144.

54 Y. Cui, C. Yang, H. Yao, J. Zhu, Y. Wang, G. Jia, F. Gao and J. Hou, Adv. Mater., 2017, 29, 1703080.

55 L. Ye, W. Zhao, S. Li, S. Mukherjee, J. H. Carpenter, O. Awartani, X. Jiao, J. Hou and H. Ade, Adv. Energy Mater., 2017, 7, 1602000.

56 S. Li, L. Ye, W. Zhao, S. Zhang, H. Ade and J. Hou, Adv. Energy Mater., 2017, 7, 1700183.

57 Y. Yi, H. Feng, M. Chang, H. Zhang, X. Wan, C. Li and Y. Chen, J. Mater. Chem. A, 2017, 5, 17204.

58 F. Yang, C. Li, W. Lai, A. Zhang, H. Huang and W. Li, Mater. Chem. Front., 2017, 1, 1389.

59 S. C. Price, A. C. Stuart, L. Yang, H. Zhou and W. You, J. Am. Chem. Soc., 2011, 133, 4625.

60 W. Li, S. Albrecht, L. Yang, S. Roland, J. R. Tumbleston, T. McAfee, L. Yan, M. A. Kelly, H. Ade, D. Neher and W. You, J. Am. Chem. Soc., 2014, 136, 15566.

61 I. Riedel, J. Parisi, V. Dyakonov, L. Lutsen, D. Vanderzande and J. C. Hummelen, Adv. Funct. Mater., 2004, 14, 38.

62 V. D. Mihailetchi, L. J. A. Koster, J. C. Hummelen and P. W. M. Blom, Phys. Rev. Lett., 2004, 93, 216601.

63 A. Hexemer, W. Bras, J. Glossinger, E. Schaible, E. Gann, R. Kirian, A. MacDowell, M. Church, B. Rude and H. Padmore, J. Phys.: Conf. Ser., 2010, 247, 012007.

64 V. D. Mihailetchi, L. J. A. Koster, J. C. Hummelen and P. W. M. Blom, Phys. Rev. Lett., 2004, 93, 216601. 